\title{
CORRESPONDÊNCIA
}

\section{Centronuclear myopathy: subgroup characterized by tissue mosaicism}

In their interesting contribution on centronucelar myopathy Zanoteli et al. ${ }^{1}$ discuss the problems of subclassification of this disease. Whereas the creation of the entity "type fiber hypotrophy and central nuclei" is very controversial and has not generally been accepted, as the authors mention, the separation of the entity "severe neonatal form linked to chromosome Xq28" seems to be justified.

The diagnosis of centronuclear myopathy is made by histologic analysis of the biopsy specimens by light microscopy, eventually complemented by enzyme histochemistry and electron microscopy, but, generally these investigations do not seem to provide important additional information justifying subclassification on morphological criteria. Actually, the disease is divided according to the period of onset of signs and symptoms and the degree of muscular involvement into: 1. severe neonatal, 2. childhood onset and 3. adult onset ${ }^{1}$.

In order to suggest another way to classify centronuclear myopathy we would like to remember that there is a subgroup of this disease characterized by muscle tissue mosaicism with a considerably reduced (haploid or near haploid) DNA content of muscle cell nuclei ${ }^{2,3}$, whereas the DNA content of fibrocytes seems to be unaffected ${ }^{2}$. Clinico-pathological correlations suggest that there is probably no relationship between the haploid or "near" haploid subtype and peculiar clinical or morphological features, but unfortunately there are very few investigations of the DNA content in this disease related in the literature up to now ${ }^{2,3}$. Therefore we would like to encourage the investigation of the DNA content in muscle biopsies of centronuclear myopathy. Nowadays, this can be done retrospectively on paraffin-embedded or frozen material from biopsies or autopsies, using flow cytometry, microspectrophotometry or image analysis techniques ${ }^{2-4}$. We think that these investigations could be very important for the understanding of centronuclear myopathy, especially regarding its aetiopathogenesis, which certainly is different in patients with or without muscle tissue mosaicism.

In summary we think its worthwile to investigate DNA of muscle biopsies in all patients with centronuclear myopathy.

Konradin Metze MD, PhD

Researcher of the National Research Council (CNPq)

Department of Pathology

State University of Campinas, UNICAMP

13081-900 Campinas SP, Brazil

e-mail: kmetze@lexxa.com.br

\section{REFERENCES}

1. Zanoteli E, Oliveira ASB, Kiyomoto BH, Schmidt B, Gabbai AA. Centronucelar myopathy: histopathological aspects in ten patients with childhood onset. Arq Neuropsiquiatr 1998;56:1-8.

2. Zimmermann P, Weber U. Familial centronuclear myopathy: a haploid DNA disease ? Acta Neuropathol (Berl) 1979;46:209-214.

3. Metze K, Schnabel R, Mellin W, Gullotta F, Hiddemann W. Heterogeneity of centronucelar myopathy shown by flow cytometry of nuclear DNA. Neuropathol Appl Neurobiol 1993;19:182-184.

4. Lee S, Tolmachoff, Marchevsky AM. DNA content analysis ("ploidy") by image analysis: clinical applications and comparison with flow cytometry. In Marchevsky AM, Bartels PH (eds). Image analysis: a primer for pathologists. New York: Raven Press, 1994:261-307. 


\section{AUTHOR'S RESPONSE}

Myotubular/Centronuclear myopathy (CNM) presents a great clinical and genetic heterogeneity. According to the period of onset of the signs and symptoms and degree of muscular involvement, three forms of disease were eventually recognized: 1) severe neonatal (X-linked recessive form); 2) childhood onset; 3 ) adult onset ${ }^{1}$.

The major evolution in the aetiopathogenesis of CNM was the detection of the first mutation in a gene localized at chromosome $\mathrm{X}(\mathrm{Xq} 28)$ in patients with severe neonatal form ${ }^{2}$. This gene encodes a protein called miotubularin. Many mutations in this gene have been identified in this clinical form ${ }^{3}$. Genetic defect still has not been identified in the other two forms of the disease. The difficulty to detect specific DNA abnormalities shows the great heterogeneity of these clinical forms. $\mathrm{CNM}$ is a rare disease and many cases are sporadic. Therefore collaborative works with a big number of the patients, especially with big families, are necessary to detect genetic defects in the other two forms of the disease.

The recent studies have not adopted the quantification of the DNA content as diagnostic criteria for differentiation of disease, as related to the last consortium of $\mathrm{CNM}^{4}$. However, a reduced DNA content of muscle cell nuclei observed in some patients with CNM may eventually characterize a specific subgroup of the disease ${ }^{5,6}$. Certainly this finding should be confirmed in a great number of patients and will help in the subclassification of the disease.

\section{REFERENCES}

1. Zanoteli E, Oliveira ASB, Schmidt B, Gabbai AA. Centronuclear myopathy: clinical aspects of ten Brazilian patients with childhood onset. J Neurol Sci 1998;158:76-82.

2. Thomas NST, Sarfarazi M, Roberts K, Williams H, Cole G, Liechti-Gallati S, Harper PS. X-Linked myotubular myopathy (MTM1): evidence for linkage to Xq28 DNA markers. Cytogenet Cell Genet 1987;46:704.

3. Laporte J, Guiraud-Chaumeil C, Vincent MC, Mandel JL, Tanner SM, Liechti-Gallati S, Wallgren-Pettersson C, Dahl N, Kress W, Bolhuis PA, Fardeau M, Samson F, Bertini E. Mutations in the MTM1 gene implicated in X-linked myotubular myopathy. ENMC international consortium on Myotubular Myopathy. European Neuro-muscular Center. Hum Mol Genet 1997;6:1505-1511.

4. Wallgren-Pettersson C. $58^{\text {th }}$ ENMC workshop: myotubular myopathy 20-22 March, 1998, Naarden, The Netherlands. Neuromuscul Disord 1998;8(7)521-525.

5. Metze K, Schnabel R, Mellin W, Gullotta F, Hiddemann W. Heterogeneity of centronuclear myopathy shown by flow cytometry of nuclear DNA. Neuropathol Appl Neurobiol 1993;19:182-184.

6. Zimmermann P, Weber U. Familial centronuclear myopathy: a haploid DNA disease? Acta Neuropathol (Berl) 1979;46:209-214.

\section{Edmar Zanoteli, $M D$}

Department of Neurology, UNIFESP-EPM

Rua Botucatu, 740, São Paulo, Brazil - 04023-900.

e-mail: zanoteli@sol.com.br 